\title{
Conversion of Nuclear Waste to Molten Glass: Formation of Porous Amorphous Alumina in a High-Al Melter Feed
}

\author{
Kai Xu ${ }^{\mathrm{a},{ }^{,}}$, Pavel Hrma ${ }^{\mathrm{a}, *}$, Nancy Washton ${ }^{\mathrm{a}}$, Michael J. Schweiger ${ }^{\mathrm{a}}$, and Albert A. Kruger ${ }^{\mathrm{b}}$ \\ ${ }^{a}$ Pacific Northwest National Laboratory, Richland, Washington 99352, United States \\ ${ }^{\mathrm{b}}$ U.S. Department of Energy, Office of River Protection, Richland, Washington 99352, United \\ States
}

\begin{abstract}
The transition of $\mathrm{Al}$ phases in a simulated high-Al high-level nuclear waste melter feed heated at $5 \mathrm{~K} \mathrm{~min}^{-1}$ to $700^{\circ} \mathrm{C}$ was investigated with transmission electron microscopy, ${ }^{27} \mathrm{Al}$ nuclear magnetic resonance spectroscopy, the Brunauer-Emmett-Teller method, and X-ray diffraction. At temperatures between 300 and $500^{\circ} \mathrm{C}$, porous amorphous alumina formed from the dehydration of gibbsite, resulting in increased specific surface area of the feed $\left(\sim 8 \mathrm{~m}^{2} \mathrm{~g}^{-1}\right)$. The high-surface-area amorphous alumina formed in this manner could potentially stop salt migration in the cold cap during nuclear waste vitrification.
\end{abstract}

Keywords: Nuclear Waste; Vitrification; Cold cap; Amorphous alumina.

\footnotetext{
*Corresponding author.

E-mail address: kai.xu@pnnl.gov (K.Xu) or pavel.hrma@pnnl.gov (P. Hrma).
} 


\section{Introduction}

Over $200,000 \mathrm{~m}^{3}$ of hazardous nuclear wastes are currently stored in 177 underground tanks at the Hanford Site near Richland, Washington, USA. The waste was produced during reprocessing of spent nuclear fuels to extract $\mathrm{Pu}$ in support of the nation's defense programs between 1944 and 1989 [1,2]. The initial part of reprocessing comprised chemical dissolution of cladding and the spent fuel, following three extraction processes: (i) bismuth phosphate carrier precipitation, (ii) REDOX solvent extraction, or (iii) PUREX. $\mathrm{Al}^{3+}$ is one of the most prevalent constituents in the waste, since (i) more than $90 \mathrm{wt} \%$ of the spent fuel at the Hanford Site was Al clad, and (ii) aluminum nitrate nonahydrate $\left[\mathrm{Al}\left(\mathrm{NO}_{3}\right)_{3} \cdot 9 \mathrm{H}_{2} \mathrm{O}\right]$ was added as a salting agent in the REDOX process $[3,4]$. Gibbsite $\left[\mathrm{Al}(\mathrm{OH})_{3}\right]$ is assumed to be the most prevalent Al-bearing solid in the waste sludge [5], while the aluminate anion $\left[\mathrm{Al}(\mathrm{OH})_{4}{ }^{-}\right]$is believed to be the dominant $\mathrm{Al}$ species in the aqueous phase caustic waste [6]. In addition to $\mathrm{Al}^{3+}$, Hanford waste has large quantities of $\mathrm{Na}^{+}, \mathrm{Fe}^{3+}, \mathrm{NO}_{3}{ }^{-}, \mathrm{CO}_{3}{ }^{2-}$, organics, and many other less prevalent constituents [7].

The Hanford Waste Treatment and Immobilization Plant (WTP) currently under construction will separate the waste into Al-rich high-level waste (HLW) sludge and Na-rich low-activity waste (LAW) supernate solution [8,9]. The HLW and LAW will be immobilized in the form of glass, with the help of glass-forming additives [8-10]. The content of $\mathrm{Al}_{2} \mathrm{O}_{3}$ in the resultant HLW glass can be as high as $~ 25 \mathrm{wt} \%$ [11], while in LAW glass, it is usually less than $10 \mathrm{wt} \%$, part of which is from glass additive chemicals [12]. Study of Al-related reactions during feed-to-glass conversion has attracted interest from both the nuclear waste vitrification and glass industries to maximize the efficiency of glass melters [13,14]. 
Our recent works regarding feed-to-glass conversion show that the gibbsite in a typical simulated high-Al HLW melter feed dehydrates to amorphous alumina above $200^{\circ} \mathrm{C}$, and turns to early glass-forming phase at $\sim 700^{\circ} \mathrm{C}[15,16]$. Also, the amorphous alumina with a high specific surface area was identified with transmission electron microscopy (TEM) at temperature of $\sim 500^{\circ} \mathrm{C}$ by Monteiro et al., who investigated the microstructural and mineralogical changes of mixtures of $\mathrm{Al}\left(\mathrm{NO}_{3}\right)_{3} \cdot 9 \mathrm{H}_{2} \mathrm{O}$ with $\mathrm{NaNO}_{3}$ during heating [17]. Amorphous alumina is a natural product of thermal decomposition of gibbsite. On a large scale, activated porous alumina is manufactured by the calcination of gibbsite for use as an adsorbent or catalyst $[18,19]$.

This paper focuses on the transition of $\mathrm{Al}$ phases at temperatures below $700^{\circ} \mathrm{C}$, especially on the formation of porous amorphous alumina dehydrated from gibbsite in the high-Al HLW melter feed. We confirmed the formation of porous amorphous alumina using TEM and nuclear magnetic resonance (NMR). The amorphous alumina caused an increase in surface area between temperatures of $300^{\circ} \mathrm{C}$ and $500^{\circ} \mathrm{C}$, as estimated by the Brunauer-Emmett-Teller (BET) method. We discuss the implications of the porous amorphous alumina thus formed for the nuclear waste vitrification plant.

\section{Experimental}

The simulated high-Al HLW melter feed was prepared as slurry shown in previous studies $[13,15,16,20]$. Compositions of the batch and the target glass are listed in Table 1. After the slurry feed was dried at $105^{\circ} \mathrm{C}$ overnight, ground quartz (SIL-CO-SIL ${ }^{\circledR} 75$, US Silica) with a maximum particle size of $\sim 75 \mu \mathrm{m}$ was added and uniformly mixed with the dried feed.

Approximately 10-g feed samples were heated at the rate of $5 \mathrm{~K} \mathrm{~min}^{-1}$ from room temperature to temperatures between 300 and $700^{\circ} \mathrm{C}$ in $100^{\circ} \mathrm{C}$ intervals and then quenched in the air. A representative sample (heated to $500^{\circ} \mathrm{C}$ ) was analyzed with TEM and NMR. 
TEM was performed on a JEOL 2010F field-emission gun microscope operating at 200 $\mathrm{kV}$ to record the morphology of the sample in nanoscale. Elemental mapping was obtained with an Oxford INCA energy dispersive spectroscope with a fine probe $(0.7 \mathrm{~nm}$ diameter $)$ in scanning mode. The sample was ground using an agate mortar and pestle to crush the large clumps. The fine powder was dispersed in isopropanol, and a carbon copper grid was then passed through the solution, allowing drying. Regions of interest were identified at electron transparent edges of the fine powders.

${ }^{27} \mathrm{Al}$ direct polarization experiments were conducted on a 20-Tesla wide-bore Varian VNMRS spectrometer, using a $1.6 \mathrm{~mm}$ triple resonance probe operating in HX mode tuned to an ${ }^{27} \mathrm{Al}$ frequency of $221.4119 \mathrm{MHz}$. Samples were held at $20^{\circ} \mathrm{C}$ during acquisition of 14,440 transients using a calibrated $\pi / 20$ pulse of $0.25 \mu \mathrm{s}$, a spectrum window of $1250 \mathrm{kHz}$, a $0.5 \mathrm{~s}$ recycle delay, and a spinning speed of $34 \mathrm{kHz}$. Time-domain free-induction decays were apodized with exponential functions corresponding to $100 \mathrm{~Hz}$ of Lorentzian broadening prior to Fourier transformation. ${ }^{27} \mathrm{Al}$ resonances were referenced to $0.5 \mathrm{M}$ aqueous solution of $\mathrm{AlCl}_{3}$ at 0 ppm.

Surface area was determined using $\mathrm{N}_{2}$ adsorption/desorption in a QUANTACHROME AUTOSORB 6-B gas sorption system. The samples were degassed at $100^{\circ} \mathrm{C}$ for more than $12 \mathrm{~h}$ under vacuum. An $\mathrm{N}_{2}$ adsorption/desorption at a constant temperature of $77.4 \mathrm{~K}$ was conducted on the degassed samples $(\sim 0.6 \mathrm{~g})$. The volume of $\mathrm{N}_{2}$ gas that adsorbed/desorbed onto the surface of the sample versus the relative pressure was measured (isotherm). The surface area was determined from the isotherm using 5 points $\left(p / p_{0}=0.05-0.3\right)$ BET method.

\section{Results}


The microstructure of the feed heated to $500^{\circ} \mathrm{C}$, at which gibbsite was completely dehydrated $[15,16]$, was characterized with TEM. Two types of areas with different morphology and texture were observed: some areas appeared porous with nanometer-size pores (Fig. 1a), while others were dense solids at this scale (Fig. 1b). The amorphous phase is believed to form the porous texture [17], and the elemental mapping of porous areas consisting of $\mathrm{Al}$ and $\mathrm{O}$ (Fig. 2) indicates the formation of porous amorphous alumina. Other crystalline components, such as hematite and quartz, have compact morphology (Fig. 1b), as observed in scanning electron microscope images [15].

To verify the formation of amorphous alumina, ${ }^{27} \mathrm{Al}$ magic angle spinning (MAS)-NMR was performed on the as-prepared and $500^{\circ} \mathrm{C}$-treated feeds to determine $\mathrm{Al}$ speciation. The asprepared feed exhibits a single resonance at 9.7 ppm (Fig. 3), which is consistent with octahedrally coordinated $\mathrm{Al}^{\mathrm{VI}}$ in a gibbsite phase [21]. However, the $500^{\circ} \mathrm{C}$-treated feed exhibits a broadening and slight shift in the apparent center of mass for the octahedral $\mathrm{Al}^{\mathrm{VI}}$ resonance (Fig. 3). These changes may result from increased second-order quadrupole effects (minimized at $20 \mathrm{~T}$ ), or more likely increased site heterogeneity arising from a disordered or poorly crystalline alumina phase. In addition, two new resonances at 69.5 and 82 ppm are evident and are consistent with two distinct tetrahedrally coordinated species of $\mathrm{Al}^{\mathrm{IV}}$ (Fig. 3).

Fig. 4 plots the BET specific surface area of samples as a function of the heat-treatment temperatures. The BET surface area of the as-prepared feed (dried at $105^{\circ} \mathrm{C}$ overnight) was $\sim 1.5$ $\mathrm{m}^{2} \mathrm{~g}^{-1}$; it rapidly increased to $\sim 8 \mathrm{~m}^{2} \mathrm{~g}^{-1}$ in the sample heated to $300^{\circ} \mathrm{C}$, and remained almost constant until $500^{\circ} \mathrm{C}$. The surface area then decreased above $500^{\circ} \mathrm{C}$, and finally reached less than $1 \mathrm{~m}^{2} \mathrm{~g}^{-1}$ in the sample heated to $700^{\circ} \mathrm{C}$. 


\section{Discussion}

The crystalline phases that appeared in response to temperature were identified and quantitatively analyzed with X-ray diffraction (XRD) in previous works $[15,16]$, which allows us to assess the mole fraction of each $\mathrm{Al}$ phase among all $\mathrm{Al}$ phases (Fig. 5). More than $90 \%$ of the gibbsite remained in the dry feed, while less than $10 \%$ of gibbsite transformed to boehmite during drying at $105^{\circ} \mathrm{C}$. When the feed was heated up to $200^{\circ} \mathrm{C}$, approximately $20 \%$ of the gibbsite transformed to boehmite, and no amorphous alumina was evident. As the temperature increased to $300^{\circ} \mathrm{C}$, gibbsite-to-boehmite conversion was superseded by rapid dehydration of gibbsite where $\sim 65 \%$ of gibbsite converted to amorphous alumina at $300^{\circ} \mathrm{C}$. All gibbsite was gone before $350^{\circ} \mathrm{C}$. The boehmite remained fairly constant until $400^{\circ} \mathrm{C}$, decomposed at $\sim 500^{\circ} \mathrm{C}$, and finally disappeared before $700^{\circ} \mathrm{C}$.

The thermal decomposition of pure gibbsite consists of three steps: (i) partial dehydration of gibbsite to boehmite at $\sim 200^{\circ} \mathrm{C}$, (ii) dehydration of gibbsite to transitional alumina at $300^{\circ} \mathrm{C}$, and (iii) dehydration of the boehmite formed in the first step at $\sim 500^{\circ} \mathrm{C}[18,19,22,23]$. As a melter feed component, gibbsite follows a similar thermal decomposition path. Above $500^{\circ} \mathrm{C}$, Al-containing phases, such as aluminoborate and aluminosilicate phases, started to form from the interaction of activated amorphous alumina with alkaline oxides, borates, and silica.

TEM, XRD, and NMR analyses confirmed the transformation of crystalline gibbsite to amorphous alumina phases. Only one resonance associated with crystalline gibbsite appeared in the initial dry feed, while after heat treatment the $\mathrm{Al}^{\mathrm{VI}}$ resonance broadened, consistent with increased site heterogeneity and disorder accompanying a transition from crystalline gibbsite to an amorphous phase (Fig. 3). The feed heated to $500^{\circ} \mathrm{C}$ contained amorphous alumina $\left(\mathrm{Al}^{\mathrm{VI}}\right)$ that 
reacted with or dissolved in the early glass-forming (borate) melt, forming crystalline or amorphous aluminoborate phases as indicated by the appearance of two $\mathrm{Al}^{\mathrm{IV}}$ resonances $[24,25]$. However, the possibility of forming aluminoborate crystalline phases during sample quenching cannot be ruled out.

The as-prepared dry feed had a low specific surface area (Fig. 4), because it was a microsized solid powder. The increased surface area of feed heat treated between 300 and $500^{\circ} \mathrm{C}$ was attributed to the formation of porous amorphous alumina from dehydration of gibbsite, as TEM images and NMR spectra confirmed (Figs. 1, 2, and 3). The specific surface area of amorphous alumina was estimated to be $\sim 40 \mathrm{~m}^{2} \mathrm{~g}^{-1}$, assuming that the surface area from other components was negligible and approximately $80 \%$ of the Al turned to amorphous alumina (content of amorphous alumina in the feed: $\sim 20 \mathrm{wt} \%$ ) (Fig. 5). Above $500^{\circ} \mathrm{C}$, the surface area started to decrease, since the amorphous alumina turned to low surface area products, such as aluminoborate and aluminosilicate phases (Fig. 5).

\section{Implications for Nuclear Waste Vitrification}

Porous amorphous alumina with a high specific surface area from the dehydration of gibbsite between 300 and $500^{\circ} \mathrm{C}$ in nuclear waste melter feed would have positive consequences for the performance of the WTP nuclear waste melter. The high specific surface area of the feed can reduce or stop molten salt migration in the cold cap, a layer of reacting feed floating on the pool of molten glass, thus allowing the WTP melter to achieve a long-term undisturbed steady state. Above $300^{\circ} \mathrm{C}$, alkali salts (nitrite, sulfate, chloride, etc.) start to melt, forming a primary low viscosity melt until the temperature reaches $\sim 500^{\circ} \mathrm{C}$, at which they begin to decompose. These low viscosity melts tend to vertically drain from the reacting feed, leaving a refractory 
cold cap, and horizontally migrate after accumulation, causing corrosion of the melter wall $[26,27]$. Increasing the specific surface area of the feed helps immobilize the excess molten salts that spread by capillary forces on the fine particles and form bridges between them [28]. The porous amorphous alumina formed in the high-Al nuclear waste feed $(\sim 20 \mathrm{wt} \%$ of the feed consists of porous amorphous alumina) at temperatures below $600^{\circ} \mathrm{C}$ provides a large surface area that prevents the salt migration.

In addition, the porous amorphous alumina thus formed is a highly activated product that dissolves in the early glass-forming melt earlier than micro-sized corundum. The dissolved alumina produces viscous melt and delays the closure of open pores, which allow residual gases to escape instead of being trapped in foam [13]. Less foam would result in a higher rate of melting, because of the higher heat transfer from the melt pool to the reacting feed.

\section{Conclusions}

The formation of porous amorphous alumina dehydrated from gibbsite in a high-Al HLW melter feed, which caused an increase in specific surface area of the feed at temperatures between 300 and $500^{\circ} \mathrm{C}$, was identified using TEM, NMR, and XRD. As a melter feed component, gibbsite follows a thermal decomposition path similar to that of the pure mineral, turning into activated amorphous alumina that dissolves in early glass-forming melt at temperatures above $500^{\circ} \mathrm{C}$. The porous amorphous alumina with the high specific surface area would prevent molten salt migration in the cold cap at temperatures between 300 and $500^{\circ} \mathrm{C}$ and help increase the rate of melting.

\section{Acknowledgements}


This work was undertaken with funding authorized by Federal Project Director William F. Hamel, Jr. of the U.S. Department of Energy (DOE) Waste Treatment and Immobilization Plant. Pacific Northwest National Laboratory is operated by Battelle Memorial Institute for the U.S. Department of Energy under contract DE-AC05-76RL01830. The authors would like to thank Xiaohong Shari Li for BET surface area measurement, Matthew J. Olszta for performing TEM, and Jaehun Chun, Yeong-Shyung Chou, Seung Min Lee, and Brian Riley for insightful discussions and comments.

\section{References}

[1] DOE, Plutonium: The First 50 Years, United States Plutonium Production, Acquisition, and Utilization from 1944 through 1994, DOE/DP-0137, U.S. Department of Energy, Washington, DC, 1996.

[2] R. E. Gephart, A Short History of Hanford Waste Generation, Storage, and Release, PNNL13605 Rev. 4, Pacific Northwest National Laboratory, Richland, WA, 2003.

[3] M. J. Kupfer, A. L. Boldt, K. M. Hodgson, et al., Standard Inventories of Chemicals and Radionuclides in Hanford Site Tank Wastes, HNF-SD-WM-TI-740 Rev. 0C, Lockheed Martin Hanford Corporation, Richland, WA, 1999.

[4] J. G. Reynolds, The Apparent Solubility of Aluminum (III) in Hanford High-Level Waste, WRPS-52968 Rev. 0, Washington River Protection Solutions, LLC, Richland, WA, 2012.

[5] K. M. Krupka, K. J. Cantrell, H. T. Schaef, B. W. Arey, S. M. Heald, W. J. Deutsch, M. J. Lindberg, Characterization of Solids in Residual Waste from Single-Shell Tanks at the Hanford Site, Washington, USA-9277, Waste Management Symposium, Phoenix, AZ, 2009.

[6] C. T. Johnston, S. F. Agnew, J. R. Schoonover, J. W. Kenney, B. Page, J. Osborn, R. Corbin, Environ. Sci. Technol., 36 (2002) 2451-2458. 
[7] W. J. Deutsch, K. J. Cantrell, K. M. Krupka, M. L. Lindberg, R. J. Serne, Applied Geochemistry, 26 (2011) 1681-1693.

[8] D. K. Peeler, J. D. Vienna, M. J. Schweiger, K. M. Fox, Advanced High-Level Waste Glass Research and Development Plan, PNNL-24450, Pacific Northwest National Laboratory, Richland, WA, 2015.

[9] D. K. Peeler, D-S. Kim, J. D. Vienna, M. J. Schweiger, G. F. Piepel, Office of River Protection Advanced Low-Activity Waste Glass Research and Development Plan, PNNL-24883, Pacific Northwest National Laboratory, Richland, WA, 2015.

[10] I. L. Pegg, Physics Today, 68 (2015) 33-39.

[11] K. S. Matlack, G. Gan, M. Chaudhuri, W. Kot, W. Gong, T. Bardakci, I. L. Pegg, Melt Rate Enhancement for High Aluminum HLW Glass Formulations, VSL-08R1360-1 Rev. 0, Vitreous State Laboratory, The Catholic University of America, Washington, DC. 2008.

[12] G. F. Piepel, S. K. Cooley, J. D. Vienna, J. V. Crum, Experimental Design for Hanford Low-Activity Waste Glasses with High Waste Loading, PNNL-24391, Pacific Northwest National Laboratory, Richland, WA, 2015.

[13] D. A. Pierce, P. Hrma, J. Marcial, B. J. Riley, M. J. Schweiger, Int. J. Appl. Glass Sci., 3 (2012) 59-68.

[14] A. Christmann, J. Deubener, O. Hochrein, M. Mondeshki, Int. J. Appl. Glass Sci., published online, DOI: 10.111/IJAG.12183 (2016).

[15] K. Xu, P. Hrma, J. Rice, B. J. Riley, M. J. Schweiger, J. V. Crum, J. Am. Ceram. Soc., 98 (2015) 3105-3111.

[16] K. Xu, P. Hrma, J. Rice, M. J. Schweiger, B. J. Riley, N. R. Overman, A. A. Kruger, J. Am. Ceram. Soc., accepted (2016). 
[17] A. Monteiro, S. Schuller, M. J. Toplis, R. Podor, J. Ravaux, N. Clavier, H. P. Brau, T.

Charpentier, F. Angeli, and N. Leterrier, J. Nucl. Mater., 448 (2014) 8-19.

[18] J. Rouquerol, F. Rouquerol, M. Ganteaume, J. Catal., 57 (1979) 222-230.

[19] M. H. Stacey, Langmuir, 3 (1987) 681-686.

[20] M .J. Schweiger, P. Hrma, C. J. Humrickhouse, J. Marcial, B. R. Riley, N. E. TeGrotenhuis, J. Non-Cryst. Solids, 356 (2010) 1359-1367.

[21] T. J. Bastow, J. S. Hall, M.E. Smith, and S. Steuernagel, Mat. Lett., 18 (1994) 197-200.

[22] J. Rouquerol, F. Rouquerol, M. Ganteaume, J. Catal., 36 (1975) 99-110.

[23] J. T. Kloprogge, H. D. Ruan, R. L. Frost, J. Mater. Sci., 37 (2002) 1121-1129.

[24] R. Gresch, W. Müller-Warmuth, H. Dutz, J. Non-Cryst. Solids, 21 (1976) 31-40.

[25] M. Bertmer, L. Züchner, J. C. C. Chan, H. Eckert, J. Phys. Chem. B, 104 (2000) 6541-6553.

[26] P. Hrma, C. E. Goles, D. D. Yasuda, Drainage of Primary Melt in a Glass Batch, Nuclear Waste Management IV, Cincinnati, OH, 361-367, 1991.

[27] K. F. Whittington, D. K. Seiler, J. Luey, J. D. Vienna, W. A. Sliger, Feed Process Studies Research-Scale Melter, PNNL-11333, Pacific Northwest National Laboratory, Richland, WA, 1996.

[28] P. Hrma, L. M. Bagaasen, M. J. Schweiger, et al., Bulk Vitrification Performance Enhancement: Refractory Lining Protection Against Molten Salt Penetration, PNNL-16773, Pacific Northwest National Laboratory, Richland, WA, 2007. 


\section{Tables}

Table 1. Batch composition ( $\mathrm{g}$ ) to make $1 \mathrm{~kg}$ of glass and target glass composition

\begin{tabular}{lr||lrr}
\hline Batch composition & $\mathbf{g ~ k g}^{-1}$ & Glass composition & Mass \% & Mol.\% \\
\hline $\mathrm{SiO}_{2}$ & 305.05 & $\mathrm{SiO}_{2}$ & 30.50 & 35.05 \\
$\mathrm{Al}(\mathrm{OH})_{3}$ & 367.49 & $\mathrm{Al}_{2} \mathrm{O}_{3}$ & 24.00 & 16.25 \\
$\mathrm{H}_{3} \mathrm{BO}_{3}$ & 269.83 & $\mathrm{~B}_{2} \mathrm{O}_{3}$ & 15.21 & 15.09 \\
$\mathrm{Li}_{2} \mathrm{CO}_{3}$ & 88.30 & $\mathrm{Li}_{2} \mathrm{O}$ & 3.57 & 8.25 \\
$\mathrm{CaO}$ & 60.79 & $\mathrm{CaO}$ & 6.09 & 7.50 \\
$\mathrm{Fe}(\mathrm{OH})_{3}$ & 73.82 & $\mathrm{Fe}_{2} \mathrm{O}_{3}$ & 5.91 & 2.56 \\
$\mathrm{Fe}\left(\mathrm{H}_{2} \mathrm{PO}_{2}\right)_{3}$ & 12.42 & $\mathrm{Na}_{2} \mathrm{O}$ & 9.59 & 10.68 \\
$\mathrm{NaOH}$ & 99.41 & $\mathrm{~K}_{2} \mathrm{O}$ & 0.14 & 0.10 \\
$\mathrm{NaF}$ & 14.78 & $\mathrm{MgO}$ & 0.12 & 0.21 \\
$\mathrm{Na}_{2} \mathrm{CrO}_{4}$ & 11.13 & $\mathrm{ZrO}_{2}$ & 0.39 & 0.22 \\
$\mathrm{Na}_{2} \mathrm{SO}_{4}$ & 3.55 & $\mathrm{ZnO}_{4}$ & 0.08 & 0.07 \\
$\mathrm{NaNO}_{2}$ & 3.37 & $\mathrm{Bi}_{2} \mathrm{O}_{3}$ & 1.14 & 0.17 \\
$\mathrm{Na}_{2} \mathrm{C}_{2} \mathrm{O}_{4}$ & 1.26 & $\mathrm{NiO}_{4}$ & 0.40 & 0.37 \\
$\mathrm{KNO}_{3}$ & 3.04 & $\mathrm{PbO}_{3}$ & 0.41 & 0.13 \\
$\mathrm{Mg}_{3}(\mathrm{OH})_{2}$ & 1.69 & $\mathrm{Cr}_{2} \mathrm{O}_{3}$ & 0.52 & 0.24 \\
$\mathrm{Zr}(\mathrm{OH})_{4} \cdot 0.65 \mathrm{H}_{2} \mathrm{O}$ & 5.49 & $\mathrm{P}_{2} \mathrm{O}_{5}$ & 1.05 & 0.51 \\
$\mathrm{Zn}\left(\mathrm{NO}_{3}\right)_{2} \cdot 4 \mathrm{H}_{2} \mathrm{O}$ & 2.67 & $\mathrm{SO}_{3}$ & 0.20 & 0.17 \\
$\mathrm{Bi}(\mathrm{OH})_{3}$ & 12.80 & $\mathrm{~F}$ & 0.67 & 2.44 \\
$\mathrm{NiCO}_{3}$ & 6.36 & & & \\
$\mathrm{~Pb}_{3}\left(\mathrm{NO}_{3}\right)_{2}$ & 6.08 & & & \\
\hline Total & $\mathbf{1 3 4 9 . 3 3}$ & Total & $\mathbf{1 0 0 . 0 0}$ & $\mathbf{1 0 0 . 0 0}$ \\
\hline
\end{tabular}




\section{Figure Captions}

Fig. 1 TEM images of two types of areas, (a) porous amorphous phase and (b) solid crystalline phase, in the feed sample heated to $500^{\circ} \mathrm{C}$.

Fig. 2 (a) TEM image of porous amorphous phase, and (b) Al and (c) O elemental mapping in of area shown in panel a. The feed sample was heated to $500^{\circ} \mathrm{C}$. The color bars on the left of panels (a) and (b) indicate the different concentrations (the top color is the highest) of elements.

Fig. $3{ }^{27}$ Al MAS-NMR spectra of the dry feed as prepared and the feed heated to $500^{\circ} \mathrm{C}$.

Fig. 4 BET specific surface area (SSA) of samples as a function of heat-treatment temperature. The line was added as the guide to the eyes. The error bars $(\sim 10 \%)$ were estimated from the duplicate samples.

Fig. 5 Mole fractions of gibbsite (G), boehmite (B), intermediate crystalline Al phases (IC), and amorphous alumina (A) with respect to the total of all $\mathrm{Al}$ phases versus heat-treatment temperature. Assessment was made based on gibbsite in the initial batch and Al-containing phases identified with XRD. ${ }^{15,16}$ Al-Lines were added as guides to the eyes. The error bars $(\sim 15 \%)$ were estimated from the duplicate samples. 
(a)

\section{0 กณ}

(b)

$50 \mathrm{~nm}$

Fig. 1 


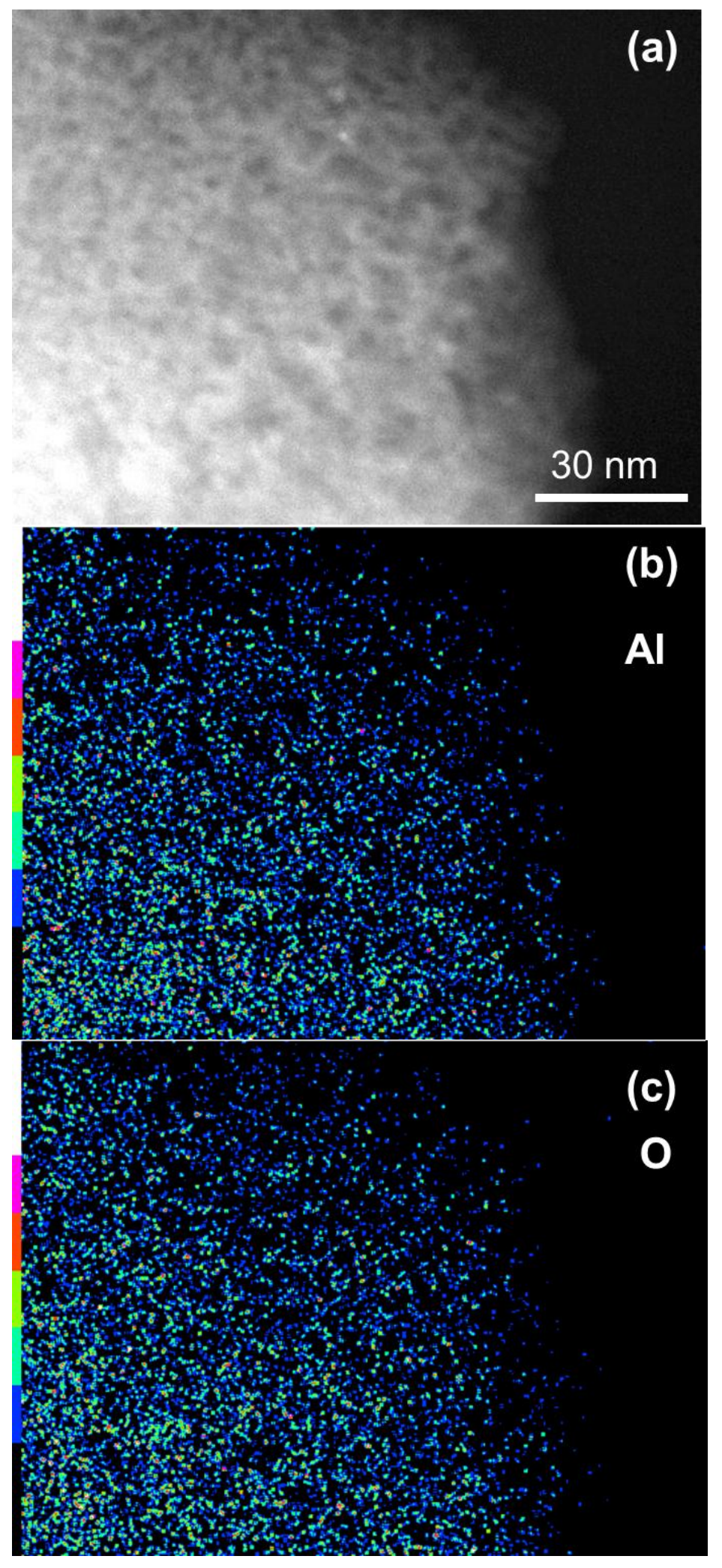

Fig. 2 


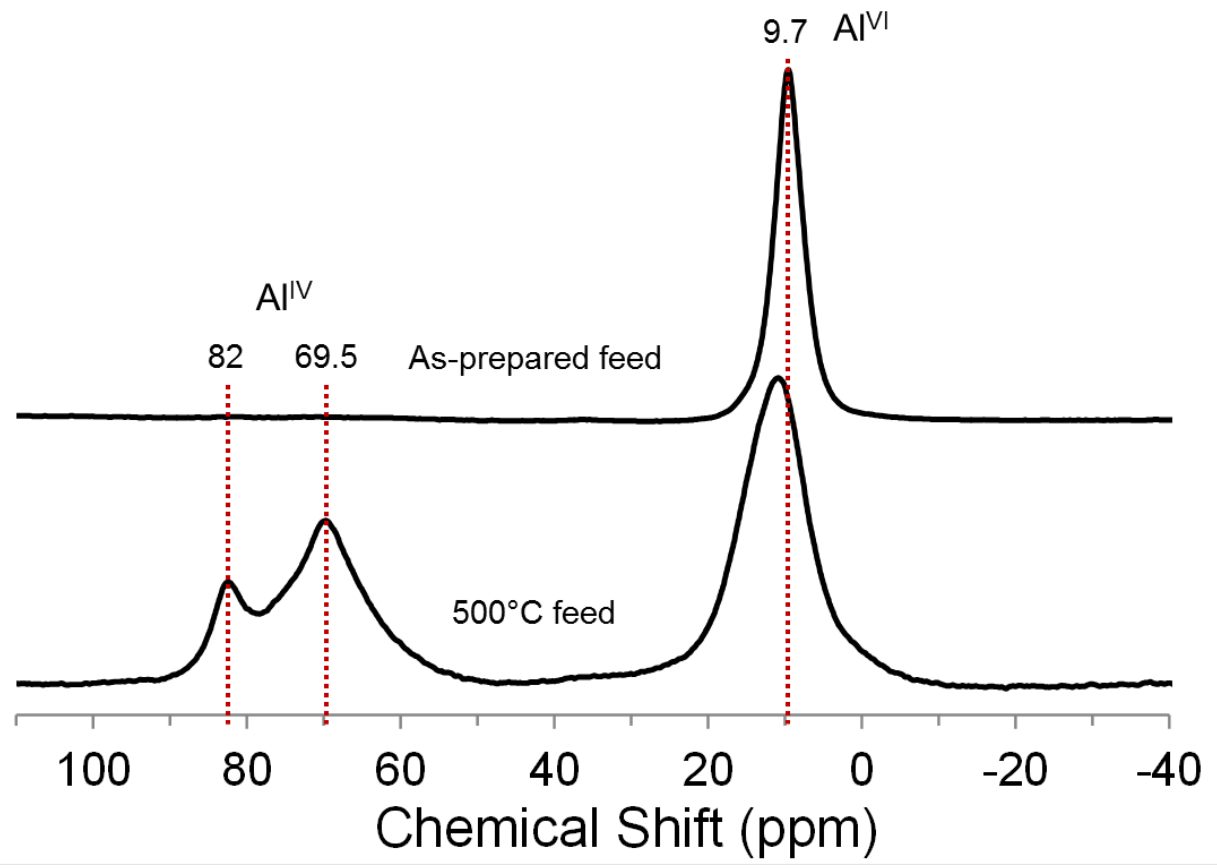

Fig. 3 


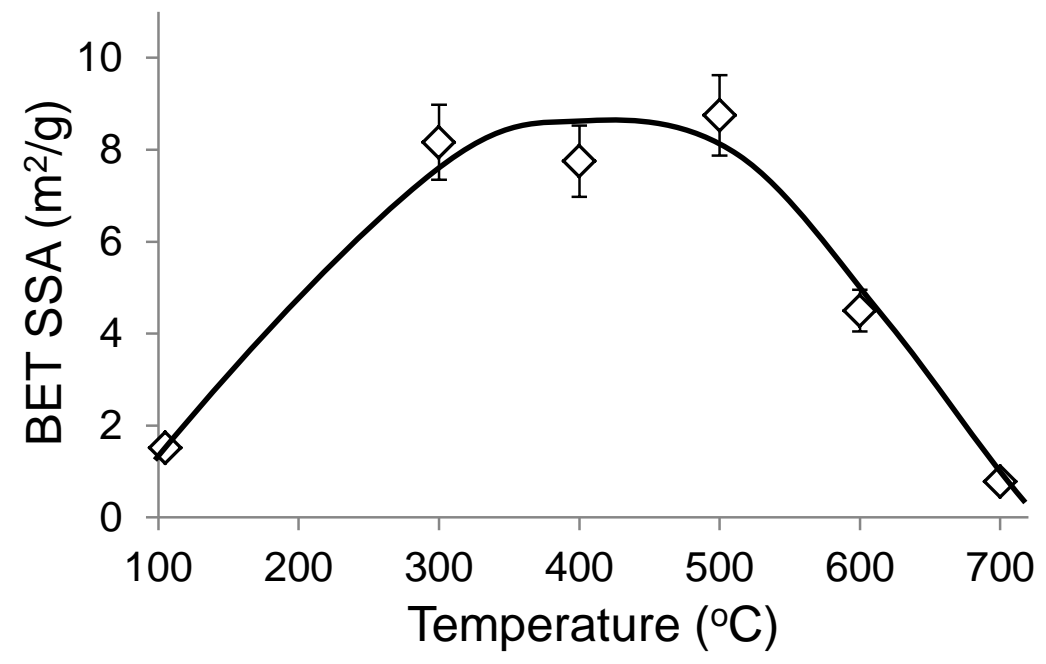

Fig. 4 


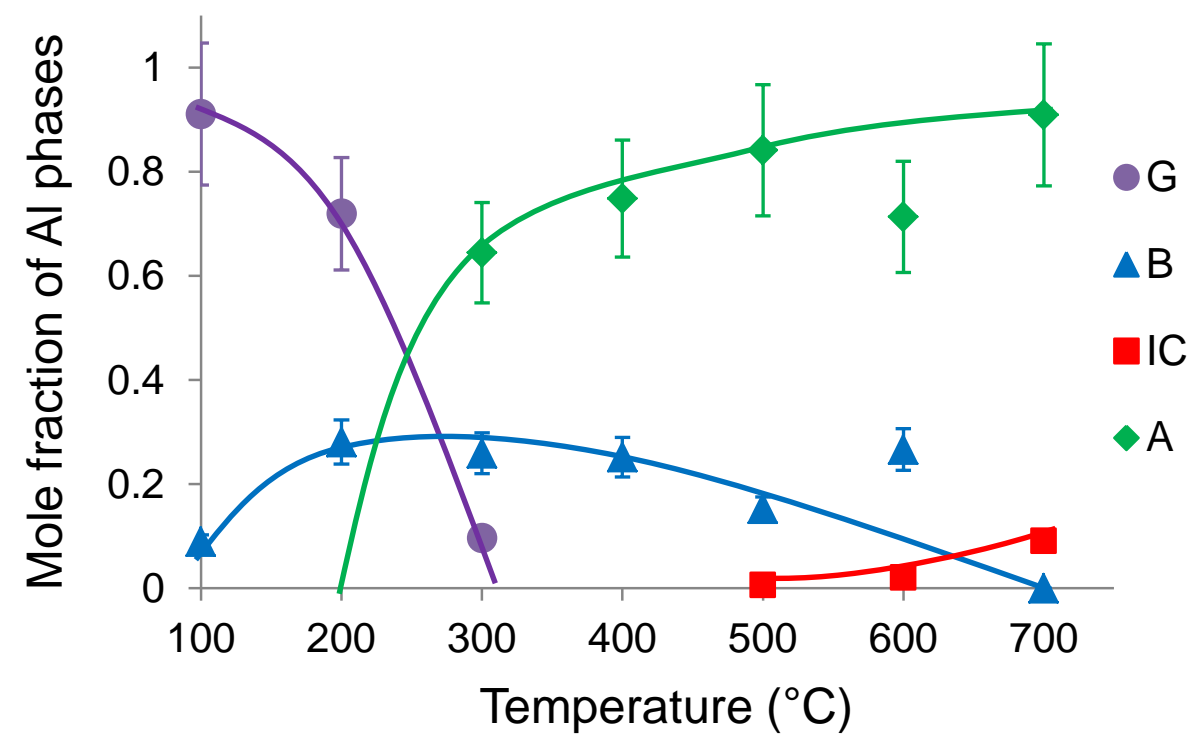

Fig. 5 